\title{
Proximate, Anti-Nutrient and Vitamin Composition of Full-Fat and Defatted Seed Flour of Telfairia occidentalis
}

\author{
Yetunde Alozie $^{1 *}$, Akaninyene Udo ${ }^{1}$, Catherine Orisa ${ }^{2}$ \\ ${ }^{1}$ Department of Home Economics, Nutrition and Dietetics, Faculty of Agriculture, University of Uyo, PMB 1017, Uyo, Nigeria \\ ${ }^{2}$ Department of Home Science, Nutrition and Dietetics, Rivers State University. PMB 5080, Port Harcourt, Nigeria
}

\section{A R T ICLE INFO}

\section{Research Article}

Received 24 September 2016

Accepted 22 September 2017

Keywords:

Anti-nutrients

Proximate composition

Telfairia occidentalis

Vitamins

Nutrients

*Corresponding Author:

E-mail: nimozmail001@gmail.com \begin{abstract}
A B S T R A C T
Studies were conducted to determine the proximate and anti-nutrient composition of fullfat and defatted seed flour of Telfairia occidentalis (fluted pumpkin) using standard procedures. The defatted seed flour (DSF) indicated higher protein content $(46.55 \%)$ while the full-fat seed flour (FSF) presented a value of $10.20 \%$. The lipid (35.78\%), carbohydrate $(42.27 \%)$, and caloric values $(531.90 \mathrm{Kcal} / 100 \mathrm{~g})$ obtained for FSF were respectively higher than values of similar determinations for DSF. The anti-nutritional analyses of the FSF showed slightly higher oxalate content $(44.00 \mathrm{mg} / 100 \mathrm{~g})$ while cyanide, phytate and tannin levels were higher in DSF. The vitamin A composition of FSF $(9.18 \mathrm{mg} / 100 \mathrm{~g})$ was higher than that of DSF $(0.84 \mathrm{mg} / 100 \mathrm{~g})$ while DSF indicated higher vitamin C $(74.44 \mathrm{mg} / 100 \mathrm{~g})$ content. These results revealed that the seed flour of Telfairia occidentalis contains an appreciable amount of nutrients and vitamins. The levels of toxicants in both FSF and DSF samples were low and below toxic levels. The seed flour of Telfairia occidentalis can be exploited as a cheap and valuable source of vegetable protein in fortified food products formulation.
\end{abstract}

DOI: https://doi.org/10.24925/turjaf.v5i11.1256-1260.992

\section{Introduction}

Vegetables serve as an indispensable constituent of human diet, supplying the body with minerals, vitamins and certain hormone precursors, in addition to protein and energy (Oyenuga and Fetuga, 1975). Telfairia occidentalis (fluted pumpkin) is a popular edible leaf and seed vegetable which belongs to the family Cucurbitaceae. It is widely cultivated throughout West Africa and is reputed for its very palatable and nutritious leaves and seeds. The leaves are rich in vitamins and minerals such as calcium, phosphorus and iron (Eseyin et al., 2014a). The seed oils have found great use in domestic cooking (Akoroda, 1990). Previous studies have shown that the leaves of $T$. occidentalis contain vitamins such as thiamine, riboflavin, nicotinamide and ascorbic acid. The leaves have also been found to contain some amino acids such as alanine, aspartate, glycine, and leucine (Fasuyi and Nonyerem, 2007; Tindall, 1968).

The medicinal potentials of various parts of $T$. occidentalis have been widely reported by previous investigators. These potentials include: anticonvulsant (Gbile, 1986), antioxidant and hepatoprotective activity (Oboh, 2005; Oboh, 2006; Bolaji and Olabode, 2011), antidiabetic activity (Aderibigbe et al., 1999; Emudianughe and Aderibigbe, 2002; Eseyin et al., 2007;
Eseyin et al., 2010a; Eseyin et al., 2010b; Eseyin et al., 2010c; Eseyin et al., 2014b), anti-cancer (Ejike and Ezeanyika, 2011a; Ejike and Ezeanyika, 2011b; Okokon et al., 2012a), anti-inflammatory and analgesic (Oluwole et al., 2003; Okokon et al., 2012b), hematological (Iweala and Obidoa, 2009; Fasuyi and Nonyerem, 2007; Hamlin and Latunde-Dada, 2011; Alada, 2000; Odede et al., 2010; Osuntoki and Sanusi, 2007). Specifically, the antimicrobial properties $T$. occidentalis have also been reported (Okokon et al., 2007; Okokon, et al., 2009; Odoemena and Essien, 1995; Noumedem et al., 2013).

A previous study has identified phytochemicals such as tannins, saponins, flavanoids and phenolics in the plant (Ekpenyong et al., 2012). The chemical composition of various parts of $T$. occidentalis has also been reported (Essien et al., 1992; Akwaowo et al., 2000; Okokon et al., 2012). To our knowledge, there is no report on the proximate and anti-nutrient composition of full-fat and defatted seed flour of Telfairia occidentalis despite its widespread acceptability as food. In this present study, the proximate, vitamin and anti-nutrient composition of fullfat and defatted seed flour of Telfairia occidentalis from Nigeria has been evaluated using standard methods. 


\section{Material and Methods}

Plant material: Healthy and mature fluted pumpkin seeds were purchased from four farms in Bori, Khana Local Government Area of Rivers State, Nigeria. Plant identification, authentication and specimen referencing were done at the Department of Botany and Ecological Studies, University of Uyo, Uyo, Nigeria. A voucher specimen has been deposited at the Herbarium of the Department of Botany and Ecological Studies.

Telfairia occidentalis seed flour production: Pumpkin seeds were manually extracted from the pod, washed, airdried and manually decorticated. The air-dried seeds were crushed into powder using an electric blender (Kenwood BL 480, United Kingdom) and divided into two equal portions. One portion (1 kg) was defatted by soaking the ground seeds in $5 \mathrm{~L}$ of $n$-hexane for $36 \mathrm{~h}$ at room temperature; with a change of solvent every $8 \mathrm{~h}$. The defatted flour mixture was filtered, concentrated to dryness using a rotary evaporator at $40^{\circ} \mathrm{C}$ and ground to pass through a $355 \mathrm{MICS}$ sieve. The second portion $(1 \mathrm{~kg})$ was not defatted. The flours were packaged in air-tight containers, designated as full-fat seed flour (FSF) and defatted seed flour (DSF) and kept in a refrigerator at $4^{\circ} \mathrm{C}$ until use. All reagents and chemicals used in this work were of analytical (AnalaR) grade and were purchased from Sigma-Aldrich chemical company, United Kingdom.

Proximate analyses: These analyses were carried out to determine the moisture, ash, crude fibre, crude fat, crude protein content in the full-fat and defatted seed flour of Telfairia occidentalis. The moisture content was determined by drying the seed flour in an oven (Gallenkamp OV-330) at $105^{\circ} \mathrm{C}$ until a constant weight was obtained (AOAC, 1990) (method 14:004). The percentage moisture content was subsequently calculated.

Total ash was determined by Furnace incineration described by AOAC (1990) (method 14:006) using about $1.0 \mathrm{~g}$ of oven-dried sample. This analytical method is based on the vaporization of water and volatiles with burning organic substances in the presence of oxygen in the air to $\mathrm{CO}_{2}$ at a temperature of $550^{\circ} \mathrm{C}$ for 5 hours. The $\%$ ash content was thereafter calculated.

Crude fibre was determined using the method of (AOAC, 1990) (method 14:020). The percentage crude fiber was also calculated using the relevant formula.

Crude protein content was calculated by converting the nitrogen content determined by Kjeldahl's method $(6.2 \mathrm{~N})$. Fat was determined by the method described by the AOAC (1990) using the Soxhlet system. The carbohydrate content was estimated as the difference obtained after subtracting the values of the organic protein, fat, ash and fiber from the total dry matter. The energy values of the samples were obtained by multiplying the values of the crude protein, lipid and carbohydrate by 4,9 and 4 respectively and taking the sum of the products.

Anti-nutrient composition: The composition of oxalate was determined using the method outlined by SanchezAlonso and Lachica (1987) and hydrocyanic acid by that of AOAC (1990). Phytic acid was determined by the method of McCance and Widdowson (1935). The FolinDenis spectrophotometric method earlier described by Pearson (1976) was used for determination of tannins.

Vitamin determination: Ascorbic acid content was obtained by the method of AOAC (1980) while the vitamin A content was determined by spectrophotometry at $620 \mathrm{~nm}$.

\section{Results and Discussion}

\section{Results}

The result of proximate composition of full-fat and defatted seed flour of Telfaria occidentalis in Table 1, Anti-nutrient profile of full-fat and defatted seed flour of Telfaria occidentalis in Table 2 and 3 Result of vitamin composition of full-fat and defatted seed flour of Telfairia occidentalis are given in Table 3

Table 1 Result of proximate composition of full-fat and defatted seed flour of Telfaria occidentalis

\begin{tabular}{l|cc}
\hline \multicolumn{1}{c|}{ Parameters } & Full-fat seed flour (FSF) & Defatted seed flour (DSF) \\
\hline Ash (\%) & $5.25 \pm 0.004$ & $9.27 \pm 0.002$ \\
Moisture (\%) & $3.00 \pm 0.001$ & $1.37 \pm 0.000$ \\
Fibre (\%) & $3.50 \pm 0.002$ & $6.18 \pm 0.003$ \\
Protein (\%) & $10.20 \pm 0.017$ & $46.55 \pm 0.032$ \\
Lipid (\%) & $35.78 \pm 0.005$ & $0.85 \pm 0.001$ \\
Carbohydrate (\%) & $42.27 \pm 0.003$ & $35.78 \pm 0.012$ \\
Energy (Kcal/100 g) & $531.90 \pm 1.005$ & $336.97 \pm 0.813$ \\
\hline
\end{tabular}

Results are Mean \pm SD of triplicate determinations in each case.

Table 2 Anti-nutrient profile of full-fat and defatted seed flour of Telfaria occidentalis

\begin{tabular}{l|cc}
\hline Parameters $(\mathrm{mg} / 100 \mathrm{~g})$ & Full-fat seed flour (FSF) & Defatted seed flour (DSF) \\
\hline Cyanide & $18.89 \pm 0.007$ & $19.23 \pm 0.012$ \\
Total oxalate & $44.00 \pm 0.003$ & $35.20 \pm 0.002$ \\
Soluble Oxalate & $26.40 \pm 0.018$ & $17.60 \pm 0.015$ \\
Phytate & $14.80 \pm 0.011$ & $16.24 \pm 0.005$ \\
Tannins & $2.29 \pm 0.001$ & $3.31 \pm 0.003$ \\
\hline
\end{tabular}

Results are expressed as Mean \pm SD of triplicate determinations in each case. 
Table 3 Result of vitamin composition of full-fat and defatted seed flour of Telfairia occidentalis (mg/100g)

\begin{tabular}{l|cc}
\hline \multicolumn{1}{c|}{ Sample } & Vitamin A & Vitamin C \\
\hline Full-fat seed flour (FSF) & $9.18 \pm 0.022$ & $57.50 \pm 0.621$ \\
Defatted seed flour (DSF) & $0.84 \pm 0.002$ & $74.44 \pm 0.005$ \\
\hline
\end{tabular}

Results are expressed as Mean \pm SD of three determinations in each case.

\section{Discussion}

Proximate composition: The result of proximate composition of full-fatted (FSF) and defatted (DSF) seed flour of Telfairia occidentalis is shown in Table 1. The result shows a higher value for ash, fibre, and protein content in sample DSF while the values obtained for moisture, lipid and carbohydrate levels were higher in sample FSF. The table also shows sample FSF is richer in energy compared to sample DSF.

This result indicates that ash content of the FSF sample of Telfairia occidentalis was higher than that of full-fat seed flours of Malus sylvestris (3.66\%) and Citrullus vulgaris $(3.75 \%)$ earlier reported (Samia El-Safy et al., 2012). The high ash content is usually an indication of the mineral element deposits preserved in the food materials. The crude lipid content of $0.85 \%$ obtained for DSF sample is extremely low compared to that of FSF sample (35.78\%). It is equally low when compared to defatted Citrullus vulgaris flour (5.5\%), reported by Penuel et al., (2013). Dietary fats function in increasing the palatability of food by absorbing and retaining flavors. A diet providing 1-2\% of its caloric energy as fat is said to be sufficient to human beings as excess fat consumption is implicated in certain cardiovascular disorders such as atherosclerosis, cancer and aging (Akindahunsi and Salawu, 2005).

The defatted seed flour (DSF) contains higher crude protein when compared to the FSF sample. The crude protein level of $46.55 \%$ obtained for DSF sample is also higher than that of defatted Moringa oleifera seed flour $(17.13 \%)$ earlier reported (Olagbemide and Philip, 2014) as well as those of other seed flours of apple (33.79\%) and watermelon $(30.11 \%)$ (Samia El-Safy et al., 2012). This makes the defatted seed flour of $T$. occidentalis a very rich protein source.

The crude fibre contents were considerably low in both samples with that of DSF sample being almost twice that of the FSF sample. A similar range of values was observed for the full-fat seed flour of apple (8.32\%) and watermelon $(3.47 \%)$ (Samia El-Safy et al., 2012). The crude fibre content of defatted seed flour of $T$. occidentalis $(6.18 \%)$ was however higher than $3.33 \%$ obtained for defatted Moringa oleifera seed flour (Olagbemide and Philip, 2014). The result also explains that defatting of the seeds improves the fibre content of $T$. occidentalis seeds and the high fibre content may improve bowel function and provide faecal bulk digestion.

The levels of carbohydrate were also appreciable in both samples. This makes the T. occidentalis seed flour a rich energy source. The carbohydrate level of $42.27 \%$ for FST was indeed higher than those of the full fat seed flour of Moringa oleifera (8.67\%) (Olagbemide and Philip, $2014)$ and apple $(23.50 \%)$, papaya $(22.15 \%)$, watermelon $(17.62 \%)$, guava $(10.27 \%)$, orange $(34.74 \%)$ and prickly pear $(13.45 \%)$ as earlier reports indicate (Samia El-Safy et al., 2012). However, the carbohydrate level obtained for DSF sample was lower compared to the $57.77 \%$ obtained for the defatted seed flour of Moringa oleifera (Olagbemide and Philip, 2014).

Antinutrient composition: Levels of hydrogen cyanide, oxalate, phytic acid and tannins in the full-fat seed flour (FSF) and defatted seed flour (DSF) are given in Table 2. The contents of hydrogen cyanide in both samples are low and below the lethal dose of $35 \mathrm{mg} / 100 \mathrm{~g}$ (Munro and Bassir, 1969). Also, the levels of total and soluble oxalate in both samples were extremely low and below the toxic level of 2-5 g/100 g (Onwuka, 2005). These values are however higher than $0.407 \mathrm{mg} / 100 \mathrm{~g}$ obtained for watermelon seed flour (Samia El-Safy et al., 2012). Oxalates are known to complex with calcium to form calcium crystals which get deposited as stones that are associated with blockage of renal tubules (Banso and Adeyemo, 2007). However, processing methods such as proper cooking are known to significantly reduce total oxalate content in vegetables (Akwaowo et al., 2000). Based on our investigation, it could be safely speculated that there is no danger of toxicity associated with oxalate content in the plant under study. The levels of tannins in both samples were slightly higher than the value of 0.17 $\mathrm{mg} / 100 \mathrm{~g}$ earlier reported for the seed flour of Cucurbitapepo, another variety of pumpkin (El-Adawy and Taha, 2001). Also, phytic acid levels for both FSF and DSF samples were quite high compared to the value of $2.27 \mathrm{mg} / 100 \mathrm{~g}$ obtained for the seed flour of Cucurbitapepo (El-Adawy and Taha, 2001).

Vitamin composition: The vitamin content of full-fat and defatted seed flour of Telfairia occidentalis is shown in Table 3. This result reveals a higher value (74.44 $\mathrm{mg} / 100 \mathrm{~g}$ ) for vitamin $\mathrm{C}$ in the defatted sample (DSF) compared to $57.50 \mathrm{mg} / 100 \mathrm{~g}$ observed for the full-fat seed flour (FSF) counterpart. A trace amount of vitamin A was also obtained $(0.84 \mathrm{mg} / 100 \mathrm{~g})$ in the DSF sample. It has been reported that edible plants possess chemo-preventive and chemo-protective activities which have been attributed to dietary constituents such as vitamin $\mathrm{E}$, vitamin C, and more recently, polyphenols (Lee et al., 2009). The wound healing property of ascorbic acid has been earlier reported (Bursal et al., 2013) and the values obtained in this study support its usage for wound healing especially for children and women older than 18 years of age as it contributes excellently to their recommended daily intake.

\section{Conclusion}

The result of this study has shown that the full-fat and defatted seed flour of Telfairia occidentalis (fluted pumpkin) contain an appreciable amounts of 
carbohydrate, protein, fibre and fat in addition to variable amounts of vitamin A and C. The low levels of antinutrients suggest that the consumption of seed flour of $T$. occidentalis is not harmful and therefore not expected to produce any adverse health effects. This study, therefore, concludes that $T$. occidentalis seed flour can contribute significantly to the human nutritional requirements as dietary supplements both for domestic use and industrially in the production of confectionaries and other food items.

\section{References}

Aderibigbe A, Lawal B, Oluwagbemi J. 1999. The antihyperglycaemic effect of Telfairia occidentalis in mice. African Journal of Medicine and Medical Sciences 28 (3-4):171-175. http://www.ncbi.nlm.nih.gov/pubmed/11205825.

Akindahunsi AA, Salawu SO. 2005. Phytochemical screening and nutrient-antinutrient composition of selected tropical green leafy vegetables. African Journal of Biotechnology 4 (6):497-501. http://www.ajol.info/index.php/ajb/article/view/15128. ISSN: 1684-5315.

Akoroda MO. 1990. Ethnobotany of Telfairia occidentalis (Cucurbitaceae) among Igbos of Nigeria. Economy Botany 44(1): 29-39. DOI: 10.1007/BF02861064.

Akwaowo EU, Ndon BA, Etuk EU. 2000. Minerals and antinutrients in fluted pumpkin (Telfairia occidentalis Hook) Food Chemistry -Analytical, Nutritional and Clinical Methods Section 70 (2): 235-240. http://dx.doi.org/10.1016/S0308-8146 (99)00207-1.

Alada A. 2000. The haematological effect of Telferia occidentalis diet preparation. African Journal of Biomedical Research, 3(1): 185-186. www.bioline.org.br/pdf?md00051.

AOAC. 1980. Official Methods of Analysis. 13th Ed. Washington DC, New York. p. 55

AOAC. 1990. Official methods of analysis. 15th Edition, Helrich, K. (ed) Association of official analytical chemists, Washington DC, USA.

Banso A, Adeyemo SO. 2007. Evaluation of antimicrobial properties of tannins isolated from Dichrostachys cinerea. African Journal of Biotechnology 6 (15):1785-1787. http://dx.doi.org/10.5897/AJB2007.000-2262 ISSN: 1684-5315.

Bolaji O, Olabode O. 2011. Modulating effect of aqueous extract of Telfairia occidentalis on induced cyanide toxicity in rats. Nigerian Journal Physiological of Sciences 26 (2):185-191. ISSN: 0794-859X.

Bursal E, Koksal E, Gulcin I, Goren AC. 2013. Antioxidant activity and polyphenol content of cherry stem (Ceraus avium L) determined by LC-MS/MS. Food Research International 51 (1):66-74. http://dx.doi.org/10.1016/j.foodres.2012.11.022. DOI : 10.9734/ARRB/2014/8476

Ejike CECC, Ezeanyika LU. 2011b. Inhibition of the experimental induction of benign prostatic hyperplasia: A possible role for fluted pumpkin (Telfairia occidentalis Hook F.) seeds. Urologia Internationalis 87(2): 218-224. DOI:10.1159/000327018.

Ejike CECC, Ezeanyika LUS. 2011a. Management of experimental benign prostatic hyperplasia in rats using a food based therapy containing Telfairia occidentalis seeds. African Journal of Traditional Complementary and Alternative Medicine 8(4):398404. http://dx.doi.org/10.4314/ajtcam.v8i4.9.

Ekpenyong, C. E., Akpan, E. E, Udoh, N. S. (2012). Phytochemistry and toxicity studies of Telfairia occidentalis aqueous leaves extract on liver biochemical indices in wistar rats. American Journal of Medicine and Medical Sciences 2(5): 103-110. DOI: 10.5923/j.ajmms.20120205.03.

El-Adawy TA, Taha KM. 2001. Characteristics and compositions of different seed oils and flours. Food Chemistry 74(1):47-54. DOI: $10.1016 / \mathrm{S} 0308-8146(00) 00337-\mathrm{X}$.
Emudianughe TS, Aderibigbe AO. 2002. The hypoglycaemia effect of Telfaria occidentalis aqueous leaf extract in rats. West African Journal of Pharmacology andDrug Research 18: 14-16. http://dx.doi.org/10.4314/wajpdr.v18i1.14720.

Eseyin O, Ebong P, Eyong E, Awofisayo O, Agboke A. 2010c. Effect of Telfairia occidentalis on oral glucose tolerance in rats. African Journal of Pharmacy and Pharmacology 4:368-372. ISSN 1996-0816.

Eseyin OA, Ebong P, Ekpo A, Igboasoiyi A, Oforah E. 2007. Hypoglycemic effect of the seed extract of Telfairia occidentalis in rat. Pakistan Journal of Biological Sciences 10 (3): 498-501. 10.3923/pjbs.2007.498.501.

Eseyin OA, Ebong P, Eyong EU, Umoh E, Agboke H. 2010b. Hypoglycaemic activity of ethyl acetate fraction of the leaf extract of Telfairia occidentalis. Pakistan Journal of Pharmaceutical Sciences 23 (3):341-343.

Eseyin OA, Ebong P, Eyong EU, Umoh E, Awofisayo O. 2010a. Comparative hypoglycaemic effects of ethanolic and aqueous extracts of the leaf and seed of Telfairia occidentalis. Turkish Journal of Pharmaceutical Sciences 7 (1):29-34.

Eseyin OA, Sattar MA, Rathore HA. 2014a. A review of the pharmacological and biological activities of the aerial parts of Telfairia occidentalis Hook.f. (Cucurbitaceae). Tropical Journal of Pharmaceutical Research 13 (10): 1761-1769. http://dx.doi.org/10.4314/tjpr.v13i10.28.

Eseyin OA, Sattar MA, Rathore HA, Ahmad A, Afzal S, Lazhari M, Ahmad F, Akhtar S. 2014b. Hypoglycemic potential of polysaccharides of the leaf extract of Telfairia occidentalis. Annual Research and Review in Biology 4(11): 1813-182.

Essien AI, Ebana RUB, Udo HB. 1992. Chemical evaluation of pod and pulp of the fluted pumpkin (Telfairia occidentalis) fruit. Food Chemistry 45:175-178. DOI:10.1016/03088146(92)90110-N.

Fasuyi AO, Nonyerem AD. 2007. Biochemical, nutritional and haematological implications of Telfairia occidentalis leaf meal as protein supplement in broiler starter diets. African Journal of Biotechnology 6:1055-1063. DOI: 10.5897/AJB2007.000-2136.

Gbile ZO. 1986. Ethnobotany, taxonomy and conservation of medicinal plant: In the state of medicinal plant research in Nigeria (Edited by A.O. Sofowora), P. 19.

Hamlin F, Latunde-Dada GO. 2011. Iron bioavailability from a tropical leafy vegetable in anaemic mice. Nutrition and metabolism 8:9. DOI: 10.1186/1743-7075-8-9.

ISBN 10: 019859416X / ISBN 13: 9780198594161

Iweala EJ, Obidoa O. 2009. Some biochemical, haematological and histological responses to a long term consumption of Telfairia occidentalis-supplemented diet in rats. Pakistan Journal of Nutrition 8 (8): 1199-1203. DOI: 10.3923/pjn.2009.1199.1203.

Lee H, Jung EY, Suh HJ. 2009. Chemical composition and antistress effects of yeast hydrolysate. Journal of Medicinal Food 12 (6):1281-5. DOI: 10.1089/jmf.2009.0098.

McCane RA, Widdowson EM. 1935. Phytin in human nutrition. $\begin{array}{llll}\text { Biochemical Journal. } & 29 & \text { (12): } & \end{array}$ PMCID: PMC1266816.

Munro A, Bassir O. 1969. Oxalate in Nigerian vegetables. West African Journal of Biological and Applied Chemistry 12:14-17.

Noumedem JA, Mihasan MK, Jules RS, Marius C, Dumitru D, Jean PK. 2013.In Vitro antibacterial and antibiotic-potentiation activities of four edible plants against multidrug-resistant gramnegative species. BMC Complementary and Alternative Medicine 13(1): 190-200. DOI: 10.1186/1472-6882-13-190.

Oboh G. 2005. Hepatoprotective property of ethanolic and aqueous extracts of fluted pumpkin (Telfairia occidentalis) leaves against garlic-induced oxidative stress. Journal of Medicinal Food 8(4): 560-3. DOI: 10.1089/jmf.2005.8.560.

Oboh G. 2006. Tropical green leafy vegetables prevent garlic induced hepatotoxicity in the rat. Journal of Medicinal Food 9 (4): 545-551. DOI: 10.1089/jmf.2006.9.545.

Odede TA, Ikusagba B, Odetola AA. 2010. Effect of Telfairia occidentalis on erythrocyte indices of rats following acute blood loss. African Journal Medicine and Medical Sciences 39: 117121. PMID: 22416653. 
Odoemena CS, Essien JP. 1995. Antibacterial activity of the root extract of $T$. occidentalis (fluted pumpkin). West African Journal of Biology and Applied Chemistry 40:1-4.

Okokon J, Ekpo A, Eseyin O. 2007. Antiplasmodial activity of ethanolic root extract of Telfairia occidentalis. Research Journal of Parasitology 2 (2):94-98. DOI: 10.3923/jp.2007.94.98.

Okokon JE, Dar A. Choudhary MI. 2012b. Chemical constituents and analgesic activity of Telfaria occidentalis. Phytopharmacology 3:359-366.

Okokon JE, Ekpo AJ, Eseyin OA. 2009. Evaluation of in vivo antimalarial activities of ethanolic leaf and seed extracts of Telfairia occidentalis. Journal of Medicinal Food 12 (3): 649653. DOI: 10.1089/jmf.2008.0099.

Okokon JE, Farooq AD, Choudhary MI, Antia BS. 2012a. Immunomodulatory, anticancer and anti-inflammatory activities of Telfairia occidentalis seed extract and fractions. International Journal of Food Nutrition and Safety 2 (2):72-85. ISSN: 2165896X Florida, USA.

Olagbemide PT, Philip CNA. 2014. Proximate analysis and chemical composition of raw and defatted Moringa oleifera kernel. Advances in Life Science and Technology 24:92-99. ISSN (Paper) 2224-7181 ISSN (Online) 2225-062X.

Oluwole E, Falode A, Ogundipe O. 2003. Anti-inflammatory effect of some common Nigerian vegetables. Nigerian Journal of $\begin{array}{llll}\text { Physiological } & \text { Sciences } & 18 & (1-2): 35-38\end{array}$ http://dx.doi.org/10.4314/njps.v18i1.32616.

Onwuka GI. 2005. Food analysis and instrumentation: theory and practice. Naphathali prints, Nigeria, Pp.95-96.
Osuntoki A, Sanusi A. 2007. Telfairia occidentalis extract stabilizes human erythrocyte membranes. Nigerian Quarterly Journal of Hospital Medicine 17(3):116-119. http://dx.doi.org/10.4314/nqjhm.v17i3.12557.

Oyenuga VA, Fetuga BL. 1975. Chemical composition, digestibility and energy values of some varieties of yam, cassava, sweet potatoes and cocoyams for pigs. Nigerian Journal of Science 9 (1):63-110.

Pearson D. 1976. The chemical analysis of foods. 7th ed., Churchill Livingstone, Edinburgh.

Penuel BL, Khan EM, Maitera MO. 2013. Properties of proximate composition and elemental analysis of Citrullus vulgaris (guna) seed. Bulletin of Environment, Pharmacology and Life Sciences 2 (2): 39- 46. Online: ISSN 2277-1808.

Samia El-Safy F, Salem RH, Abd El-Ghany ME. 2012. Chemical and nutritional evaluation of different seed flours as novel sources of protein. World Journal of Dairy and Food Sciences 7 (1): 59-65. DOI: 10.5829/idosi.wjdfs.2012.7.1.61215.

Sanchez-Alonso F, Lachica M. 1987. Seasonal trends in the elemental content of plum leaves. Communications in Soil Science and Plant Analysis 18 (1): 31-43. http://dx.doi.org/10.1080/00103628709367801.

Tindall HD. 1968. Commercial vegetable growing. Oxford Press. London. P. 69. ISBN: 0192943081. 